\title{
ROLE OF SPIC MACAY FOR CULTURAL TRANSMISSION AMONGST YOUTH
}

Ravi Parkash

Research Scholar, Panjab University Chandigarh

\section{ABSTRACT}

Culture is the sum of all the forms of art, morals, law, customs and any other capabilities and habits acquired by man as a member of society. Culture contributes to the harmonious development of the personality, sensitizing him towards his environment and his natural and cultural heritage. SPIC MACAY is playing an important role to impart cultural values. This paper reflects on the role of SPIC MACAY for cultural transmission amongst youth.

Keywords: SPIC-MACAY, Culture

\section{INTRODUCTION}

SPIC MACAY means Society for the Promotion of Indian Classical Music and Culture Amongst Youth. It is a non-profit, voluntary, non-political and participatory student movement registered under the Societies Registration Act, 1860 and gets the benefit of Section 80(G) tax exemption under the IT Act 1961. The movement has a central executive body in New Delhi and organises its programmes through a worldwide network of schools, colleges and educational institutions. It is supported nationally by the Ministry of Culture, Ministry of Youth Affairs and Sports, and the HRD Ministry. It is a voluntary youth movement which promotes intangible aspects of Indian cultural heritage by promoting classical dance, Indian classical music, Yoga, meditation, folk music, crafts and other aspects of Indian culture.

It is a movement with chapters in over 500 towns all over the world. It was established by Dr. Kiran Seth in 1977 at IIT Delhi but the idea of SPIC MACAY sprouted in 1972 at a concert of Ustad Nasir Aminuddin Dagar and Ustad Zia Fariduddin Dagar at the Brooklyn Academy of Music In New York. Moved by the concert, Kiran Seth helped organize a few concerts at Columbia University, New York, under the aegis of the India Club of the University during the period of 1972-76. Prof kiran Seth left his job at Bell Labs in New Jersey to return to India to teach at IIT Delhi. It was here that the idea of SPIC MACAY assumed a more defined direction in 1977.The very first concert by Dagar Brothers was held at IIT Delhi on March 28, 1978 Under MEFORG (Mechanical Engineering Final Year Operations Research Group). Another programme was organized by the group MEFYS (Mechanical Engineering Final Year Students) in 1979. This programme had a marginal attendance. A two- days programme of Ustad Bismillah Khan, Dagar Bandhu, Ustad Amjad Ali Khan and Ustad Shahid Parvez was organised at IIT Delhi. The name of SPIC MACAY was firstly launched with the aim of fighting not Westernisation but the process of deculturalisation. The first lec-dem series started in 1979 and programme moved to campuses other than IIT Delhi.

These are the following activities to enculture amongst youth

SPIC MACAY believes that there is a great deal of learning and inspiration in the heritage and arts of the world. We seek to transmit this to the youth through various activities, all involving contact and interactions with great artistes, artisans, thinkers and poets of our land.

\section{LEC-DEMS (LECTURE DEMONSTRATION)}

SPIC MACAY organizes lec-dems keeping in mind the aesthetics of the art. We endeavour to create an ambience which is free from distractions and helps the artistes take the audience deeper into their inner spaces. We enjoy organising programmes as Baithaks, bringing with it nostalgia of the traditional 'Upasak-Rasik' relationship. It is held in informal settings with a limited audience. The performer earns the invaluable 'Daad' from the audience, while the 
latter get an opportunity to steep themselves in the creative 'Rasa'-a sacred experience indeed. Masters of different forms from classical music, dance, folk music, dance and world heritage come to educational institutions and perform for the students. Lec Dems provide the stage for an informal interaction between the students and artistes, and help to create \& fine-tune a future audience. Here the artistes demonstrate the art forms with the help of explanations, thereby, making their art form easily comprehensible. The rapport thus created helps the student develop a wholesome understanding of not only the art form but also the artiste as a practitioner of a certain way of life.

\section{RURAL SCHOOL INTENSIVE}

Most of the population of India lives in the village. Keeping this in mind, SPIC MACAY began a Rural School intensive programme for rural area.Rural School Intensive (RSI) is a new initiative of SPIC MACAY to include the neglected rural children. SPIC MACAY is making a concerted effort to consciously include students from rural areas, corporation and government schools by organizing an increasing number of programmes. In this direction, in Oct 2011, SPICMACAY organised its first ever Rural School Intensive in Narendrapur village, Siwan district in Bihar. By organizing with the support of SSA and the local govt. SPICMACAY hopes to reach out to every rural child in every State. Each RSI is for 6 days where students experience yoga, learn art forms through workshops with Gurus, attend concerts by great maestros, watch classic cinema in English, Hindi and Kannada and listen to talks by eminent speakers. For each RSI, the SPD-SSA's office ensures selection of students from different schools in the region/ district. And provide basic hospitality for food and accommodation of all participants, artists and guests; make infrastructural arrangements for hosting concerts and workshops, screening classic cinema, etc. This initiative can have a profound impact on the mind of the young child, in making them more aesthetically inclined and imbibe values of discipline, focus, humility embodied in Indian culture. Most children will remember this experience life-long as they get exposure to rare art forms from the state and other parts of the country.

This activity is in tune with the recent RTE Act also and helps make education more holistic The RTE Act mentions that art education is a fundamental right of each and every child and reiterates in Schedule on p12. Section 1, Chapter V lays emphasis on values and overall development of the child. Also refer Sec 11, Chapter V, 29 (2) a,b,c,d,e. Chapter IV, 4.3.4.1 (p65) lays emphasis on nurturing aesthetic sensibility and values by integrating the arts and India's heritage of crafts in every aspect of the curriculum.

\section{NATIONAL SCHOOL INTENSIVE}

School plays a vital role in everyone's life. Schools are the best places to inspire young minds, and reaching our heritage to schools is a key part of SPIC MACAY'S movement. Thousands of its events (lec-dems, workshops, and film screenings) expose children to our heritage, SPIC MACAY also wants to create platforms for motivated students to get deeper and more transformational experiences. The National School Intensive is a week-long annual event of SPIC MACAY held exclusively for school-children. Students are given a remarkable opportunity to see and learn from various maestros and renowned artistic geniuses, an experience that is both intense and inspiring. They are also provided more than a peek into India's rich cultural tapestry with concerts, workshops, talks, cinema classics and yog sessions. Around 200-400 children (accompanied by teachers) from schools around the country gather at a host institution (usually a school) for this week long gurukul. Here's how a typical day at an NSI goes. Everyone gets up at 4 am for three hours of Naad Yog and Hath Yog. After nourishing the soul, their bodies are nourished by a scrumptious holistic breakfast. Workshops of music, dance, crafts and arts run for a full three hours every morning; with each guru imparting a unique experience to their students. The afternoon has a talk or folk performance, followed by screening of cinema classics. After a quick dinner, everyone assembles at the main hall for two performances by globallyacclaimed artists, the masters in their field. 
On the second-last day, the students of each intensive put up a short performance in front of the entire group to show what they have learnt in the $\sim 15$ hours with the gurus. The highlight of the day is an overnight concert, where 5-6 artistes perform consecutively through the night - an experience which is quite rare nowadays. On the last day the students are taken on a heritage walk to nearby places of historical significance, after which they say their goodbyes and leave for their hometowns, taking home fond memories and valuable lessons.

\section{FOLK ART AND CRAFT WORKSHOPS}

India is a country of folk art. Each province has its own folk art. Our rich heritage and culture is well embedded in our crafts and in folk. Indian folk and craft is full of variation and multiplicity in terms of themes, forms, and styles. The folk forms have contributed significantly in the development of the classical forms of the country. SPIC MACAY conducts various folk performances like Baul, Pandavani, Ottanthullal, Yakshagana, Quawali etc all over the country to inspire the youth. Different craftsmen continue to influence our heritage with various crafts such as Puppetry, Painting, Carving and Fabric Colouring etc.

During International, National and State conventions SPIC MACAY organizes various folk and craft workshops under great Gurus. So far it played a successful role in preserving and propagating the rich folk and craft tradition. Taking part in a work shop inspires and improves the learning relationship between a Guru and a pupil. Over time one develops a passion for learning more. This spirit of enquiry increases one's capacity to receive long and arduous training to put in more effort to seek perfection.

\section{BAULS}

The Bauls of Bengal were an order of musicians in 18th, 19th and early 20th century India who played a form of music using a khamak, ektara and dotara. The word Baul comes from Sanskrit batul meaning divinely inspired insanity. They are a group of Hindu mystic minstrels. Bauls travel in search of the internal ideal, Maner Manush (Man of the Heart).

\section{GOTI PUA}

The goti puas are boy dancers who dress up as girls. The word goti means 'one', 'single' and pua, 'boy', but the goti puas always dance in pairs. A goti pua presentation is ably supported by a set of three musicians, who play the pakhawaj, the geeni, or cymbals and the harmonium.

\section{YAKSHAGANA}

Yakshagana is a classical dance drama popular in the state of Karnataka. This theater art involves music, songs, dance, acting, dialogue, story and unique costumes. While songs and dance adhere to well-established talas very similar to classical Indian dance forms, acting and dialogues are created spontaneously on stage depending on the ability of artists. This combination of classical and folk elements makes yakshagana unique from any other Indian art. It would be considered a form of opera in western eyes.

\section{PUPPETRY}

A puppet is one of the most remarkable and ingenious inventions of man. Stories adapted from Puranic literature, local myths and legends usually from the content of traditional puppet theatre in India which in turn imbibes elements of all creative expressions like painting, sculpture, music, dance, drama etc. Different types of puppetry are seen across India. String puppets, Shadow puppets. Glove puppets etc. String Puppets -Marionettas having jointed limbs controlled by strings allow far greater flexibility and are, therefore, the most articulate of the puppets. Shadow Puppets -are flat figures. They are cut out of leather, which has been treated to make it translucent. Shadow puppets are pressed against the screen with a strong source of light behind it. Glove Puppets are also known as sleeve, hand or palm puppets. The head is made of either papier mache, cloth or wood, with two hands emerging from just below the neck. 


\section{WEAVING}

It is a method of fabric production in which two distinct sets of yarns or threads are interlaced at right angles to form a fabric or cloth. Cloth is usually woven on a loom, a device that holds the warp threads in place while filling threads are woven through them.

\section{KARAGATTAM}

Folk dance of Tamil country, the villagers perform this dance in praise of the rain goddess "Mari Amman". In this dance, the performers balance the water pot on their head very beautifully. Traditionally, this dance is performed in two types - Aatta Karagam is danced with decorated pots on the head and symbolizes joy and happiness, while the Sakthi Karagam is performed only in temples and is mainly danced for entertainment.

\section{BAMBOO CRAFTS}

The essential tools required fro bamboo consists of a 'dao' (billhook), a knife and a jak. The manufactures of cane and bamboo products are mostly carried on outdoors.

\section{MADHUBANI PAINTING}

Madhubani painting or Mithila painting is a style practiced in the Mithila region of Bihar. Painting is done with fingers, twigs, brushes, nib-pens and match sticks, using natural dyes and pigments and is characterized by eye- catching geometrical patterns.

\section{PATTACHITRA PAINTINGS}

The Sauras, one of the most ancient tribes of Orissa, find mention in Hindu myths, classics and even the Puranans and are noted for their Pattachitra paintings. These paintings are inspired by the Bhakti movement. They are mainly on the religious subjects that revolve around Lord Jagannath at Puri's famous Jagannath Temple. They are known for their bold lines and brilliant colours.

\section{PAPER MACHE}

It is a composite material consisting of paper pieces or pulp, reinforced with an adhesive, such as glue, starch or wall paper waste. Two main methods are used to prepare papiermache; one makes use of paper strips glued together with adhesive and the other method uses paper pulp obtained by soaking or boiling paper to which the adhesive is added. The traditional method of making papier mache adhesive is to use a mixture of water and flour or such starch, mixed to the consistency of a heavy cream.

\section{BLOCK PRINTING}

Block printing has been practiced all over India since the $12^{\text {th }}$ century. Block printing employs wooden or metal blocks to print designs and patterns on fabric by hand.

\section{KALAMKARI PAINTING}

It is a beautiful art form of Andhra Pradesh. It refers to a method of painting natural dyes onto cotton or silk fabric. Kalamkari literally means Kalam (pen) and Kari (work), which means art work done using a pen.

\section{PANDAVANI}

Pandavani is a folk singing style of musical narration of tales from ancient epic Mahabharata with musical accompaniment and Bhima as hero. This form of folk theatre is popular in the state of Chhattisgarh and in the neighbouring tribal areas of Orissa and Andhra Pradesh.

\section{BANDHEJ TIE AND DYE}

Bandhani is a type of tie-dye practiced mainly in the states of Rajasthan and Gujarat, India The term bhandhani is derived from the word 'Banda '(to tie).

\section{TERRA COTTA}

Terracotta is a type of earthern ware clay based glazed or unglazed ceramic manufactured across different regions of India. Clay figures are also made in Tamil Nadu and Pondicherry where traditionally, each village is guarded at its entrance by an enormous terracotta horse which belongs to Lord Aiyyanar who is the protector against all evils. 


\section{CONCLUSION}

In our culturally plural society, SPIC MACAY inculcates culture, art, aesthetics universal and eternal values, oriented towards the unity and integration of our people. It gives opportunity to young child in making them more aesthetically incline and imbibe values of discipline, focus, humility embodied in Indian culture and an informal interaction between the students and artistes, and help to create \& fine-tune a future audience. In short, we can say that SPIC MACAY not only transmits the culture amongst youth but also preserves our precious heritage.

\section{REFERENCES}

An Interview with Prof.Kiran Seth, IIT Delhi 2018

http://spicmacay.com/about

http://spicmacay.com/about/activities/folk-arts-crafts-workshop

http://spicmacay.com/about/activities/lecture-demonstrations

http://spicmacay.com/about/activities/national-school-intensive

http://spicmacay.com/about/activities/rural-school-intensive

https://en.wikipedia.org/wiki/Kiran_Seth

https://en.wikipedia.org/wiki/SPIC_MACAY\#cite_note-3

https://nartanam.in/

Sandesh To INFORM \& INSPIRE, 3May 2016

Sandesh To INFORM \& INSPIRE, January 2015

Shabdam, Hind Lamps Parisar, Shikohabad

Sounvenir, SPICMACAY Delhi, 2017

SPICMACAY 2nd International Convention Chennai, Tamil Nadu June 2014 